\title{
EVALUATION OF EXPERIMENTAL VACCINATION OF WHITE PEKIN DUCKS (A N AS PLATYRHYNCHOS) AGAINST NEWCASTLE DISEASE
}

\author{
M. Nishizawa ${ }^{1 *}$, A.C. Paulillo', A.C. Alessi ${ }^{1}$, A.D. N unes ${ }^{1}$, \\ J.M. Campioni' ${ }^{1}$, L.S.N . Okada' ${ }^{1}$, L. D oretto Júnior'², F.S. Lima ${ }^{3}$
}

IUniversidadeEstadual Paulista, Facul dade de Ciências Agrárias e Veterinárias, Departamento dePatologia Veterinária, Via de A cesso Prof. Paulo Donato Castellane, s/ no, CEP 14884-900, Jaboticabal, SP, Brasil.

\begin{abstract}
This study aimed the characterization of the importance of vaccination against N ewcastle disease of whitePekin duck (A nas platyrhynchos). There were used 120 Pekin ducks, distributed at random into 4 groups, vaccinated or not. At 60 days of age, all groups were challenged with a pathogenic virus (NDV) suspension, EID $_{50}=10^{8.15} / 0.1 \mathrm{~mL}$ and a group of Specific Pathogen Free (SPF) chicks were used as control of the virus. Cloacal and tracheal swabs from each bird were collected after 6, 14, 20 and 30 days post-challenge for viral isolation in SPF embryonated eggs. WhitePekin ducks of all groups did not demonstrate symptoms of the N ew castle Disease (ND). They were refractory to the ND clinical disease. In Pekin ducks from control group, the viral isolation was obtained from 20 up to 30 days after chal lenge. The NDV isolation was possible in $100 \%$ of SPF chicks that died after challenge with N D clinical signs, suggesting the possi blestate of carrier of NDV by Pekin ducks. In vaccinated groups, the viral isolation was null. It was also demonstrated therefore the relevance of the vaccination to control the virus dissemination by white Pekin ducks infected with NDV.
\end{abstract}

KEY WORDS: Pekin duck, A nas platyrhynchos, Newcastle Disease, NDV carrier, vaccination.

RESUMO

ESTUDO DA VACINAÇÃO EXPERIMENTAL DE MARRECOS DE PEQUIM ANAS PLA TYRHYNCHOS) CONTRA A DOENÇA DE NEWCASTLE. O objetivo do trabal ho foi estudar a importância da vacinação de marrecos de Pequim (A nas platyrhynchos) contra a Doença de New castle (DN). Foram utilizados 120 marrecos, distribuídos al eatoriamente em 4 grupos, vacinados ou não. A os 60 dias deidade, todos os grupos foram desafiados com uma suspensão de vírus patogênico (VDN), EID ${ }_{50}=10^{8,15} / 0,1 \mathrm{~mL}$ eum grupo deaves livres de patógenos específicos (SPF) foi utilizad o como controle do vírus. Suabes cloacai s etraqueais foram colhidos após 6, 14, 20 e30diasapóso desafio paraisolamento viral, real izado em ovosembrionadosSPF. Osmarrecos dePequim denenhum dosgrupos demonstraram sinaisclínicos da DN , mostrando-serefratários à doença clínica. N os marrecos do grupo controle, o isol amento viral foi positivo de 20 até 30 dias após o desafio, sugerindo o possível estado de portador do VDN pelos marrecos de Pequim. Foi realizado o isolamento viral em $100 \%$ das aves SPF, que apresentaram sinais clínicos evieram a óbito apóso desafio como VDN. N osgruposvacinados, o isolamento doVDN foi nulo. Taisdados demonstraram a importância da vacinação para o controle da disseminação do vírus pelos marrecos de Pequim infectados pelo VDN.

PALAVRAS-CHAVE: Marrecos de Pekin, A nas platyrhynchos, Doença de N ewcastle, estado de portador, vacinação.

\section{INTRODUCTION}

Newcastle Disease (ND) remains as the most importantpoultryvirosiswithhighlyinfectiousability, affecting domesticand wild birds. Routinevaccination combined with sacrifice of affected birds has helped to control the very virulent diseasecaused by theND virus (NDV), classified as A vian Parainfluenzavirus

\footnotetext{
¿2aboratório de Referência A nimal, Campinas, SP, Brasil.

3Ministério de Agricultura, Pecuária e A bastecimento, Brasília, DF, Brasil.

*Aluna do Programa de Pós-Graduação em Medicina Veterinária da FCA V-UNESP.
} 
type1. N ewcastlediseasehas been themain sanitary barrier for thefreecommerceof birdsand its products between countries (OFFICE InTERnational DesEpizoOtes, 1996). At the moment, the disease has a world-wide distribution with a largerank of hosts, in which 27 of the50orders of birds havebeen reported likeinfected by thisetiologicagent (KaLETA;Beldauf, 1988). In this context, there is the specie whitePekin duck, whose, commercial raising aims to the meat with high nutritious value, comes developing in Brazil. This increase in production of white Pekin duck may be dueto its potential of economicreturn. Theseanimals are easily adaptable to poultry raising conditions, with elevated production potential; however, until thepresentmoment, studiesaboutthesanitary control havenotbeen made. Inthisway, theintensiveraising, movement and the increase of these birds concentration may facilitate the dissemination of the NDV. Therefore, thisinvestigation had theobjectiveto study theimportance of thevaccination in thisspecies against N ew castl edisease, and al so to investigatethe state of NDV carrier of the Pekin duck.

\section{MATERIAL AND METHODS}

Experimental birds and management: $A$ total number of 120 day-old white Pekin ducks were distributed into four treatments of 30 birds each, as shown in Table1. Each group was divided into three repetitions with 10Pekin duckseach, housed in boxes over litter, keeping distancebetween theother groups. White Pekin ducks nutrition was based on an equilibrated diet for each different growth phase.

V accines: Recently manufacturated live NDV vaccines were applied to each experimental group according to PAULILLO (1980, 1984and 1989),PAULILLO et al. (1982), PAuLILLo et al. (1987) and PAuLILLo et al. (1996). Vaccines titer was obtained by determining $50 \%$ of the embryo-infecting dose in embryonated eggs of specific pathogen free breeders at 8 and 10 days of incubation. Thetiters of thelivevaccines with strains UIster 2C, B1 and LaSota were $7.15 \log _{10}$ $0.1 \mathrm{~mL}, 7.2 \log _{10} / 0.1 \mathrm{~mL}$ and $7.35 \log _{10} / 0.1 \mathrm{~mL}$, respectively. Birds from groups G1, G2 and G3 were vaccinated atseven daysand revaccinared at29days of age.

Table 1- Distribution of the white Pekin duck in experimental groups.

\begin{tabular}{llll} 
Group & $\begin{array}{c}\text { Vaccination } \\
\text { (7 days) }\end{array}$ & $\begin{array}{c}\text { Administration } \\
\text { route }\end{array}$ & $\begin{array}{c}\text { Revaccination } \\
\text { intra-conjunctiv } \\
\text { aroute(29days) }\end{array}$ \\
\hline G1 & Ulster 2C & Intra-conjunctiva & Ulster 2C \\
G2 & B1 & Intra-conjunctiva & B1 \\
G3 & LaSota & Intra-conjunctiva & LaSota \\
G4 & Control & - & \multicolumn{1}{c}{-} \\
\hline
\end{tabular}

Challenge:At 60 daysofage, 12 whitePekinducks from each treatment (four per repetition) were challenged with viscerotropic ND virus strain. The virus had intra-cerebral pathogenicity index of 1.78 and the embryonic death time was 48 hours, with a $50 \%$ embryo infecting dose titer of $8.15 \log _{10} 0.1 \mathrm{~mL}$. Distilled water wasused as diluent for theinoculum that was instilled by oculo-nasal rout, according to the U.S. Code of Federal Regulations (1993). In order to measure the pathogenicity of the NDV challenge strain, a group of 12 Specific-Pathogen-Free (SPF) chicks were used. The birds werehoused in isolators with filtered air and offered food and waterad li bitum.

Virus isolation: At six, 14, 20 and 30 days postchallenge, tracheal and cloacal swabs werecollected fromall birds of each grouptocarry outvirusisolation, according to methodology of REED ; MUNCH (1938).

\section{RESULTSAND DISCUSSION}

Data about the challenge with viscerotropic velogenic NDV in white Pekin ducks are shown in Table2. N oneof thePekin duck groups, vaccinated or not, presented any sign of ND after challenge, which is consistent with the observations of H IGGINS (1971). On the other hand, $100 \%$ of theSPF broilers died due to theNDV challenge. Threedays after challenge, the

Table 2- Results of challenge with vel ogenic viscerotropic N ewcastle Disease virus in whitePekin ducks at 60 days of age.

\begin{tabular}{|c|c|c|c|c|c|}
\hline Group & Vaccination (7 days) & Administration route & $\begin{array}{l}\text { Revaccination intra- } \\
\text { conjunctiva ( } 29 \text { days) }\end{array}$ & $\begin{array}{l}\text { Number } \\
\text { of birds }\end{array}$ & \%Total protection \\
\hline G1 & Ulster 2C & Intra-conjunctiva & Ulster 2C & 12 & 100.0 \\
\hline G2 & $\mathrm{B} 1$ & Intra-conjunctiva & $\mathrm{B} 1$ & 12 & 100.0 \\
\hline G3 & LaSota & Intra-conjunctiva & LaSota & 12 & 100.0 \\
\hline G4 & Control & - & - & 12 & 100.0 \\
\hline G5 & SPF chicks & - & - & 12 & 0.0 \\
\hline
\end{tabular}


Table 3 - Results of virus (NDV) isolation from white Pekin ducks (60 days of age) after challenge.

\begin{tabular}{|c|c|c|c|c|c|c|c|c|c|c|}
\hline \multirow[t]{3}{*}{ Group } & \multirow{3}{*}{$\begin{array}{l}\text { Vaccination } \\
\text { (7 days) }\end{array}$} & \multirow{3}{*}{$\begin{array}{l}\text { Revaccination intra- } \\
\text { conjunctiva route ( } 29 \text { days) }\end{array}$} & \multicolumn{8}{|c|}{ Viral isolation } \\
\hline & & & \multicolumn{2}{|c|}{ 6DAC } & \multicolumn{2}{|c|}{ 14DAC } & \multicolumn{2}{|c|}{$20 \mathrm{DAC}$} & \multicolumn{2}{|c|}{$30 \mathrm{DAC}$} \\
\hline & & & $\mathrm{T}$ & $\mathrm{C}$ & $\mathrm{T}$ & $\mathrm{T}$ & $\mathrm{C}$ & $\mathrm{T}$ & $\mathrm{T}$ & C \\
\hline G1 & Ulster 2C & Ulster 2C & - & - & - & - & - & - & - & - \\
\hline $\mathrm{G} 2$ & $\mathrm{~B} 1$ & B1 & - & - & - & - & - & - & - & - \\
\hline G3 & LaSota & LaSota & - & - & - & - & - & - & - & - \\
\hline G4 & Control & - & - & - & - & - & + & + & + & + \\
\hline
\end{tabular}

$\mathrm{T}=$ Trachea, $\mathrm{C}=$ Vent, $\mathrm{DAC}=$ Days after challenge, $+=$ positive isolation, $-=$ negative isolation

SPF chicks began to present clinical signs such as ruffled feathers, anorexia, depression, conjunctivitis, dyspnea, respiratory disorders, severe and green diarrhea and death. At necropsy, were observed necrotic lesions in the trachea accompanied by catarrhal exsudate in the lumen, petechial hemorrhages in theproventriculus and hemorrhages in the small intestine and cecal tonsils. NDV was isolated from these SPF chicks, indicating theability of the NDV used in this trial to cause disease.

Table 3 shows the results of viral isolation. The NDV was isolated from Pekin ducks of the control group (non-vaccinated against ND - G4 group) at 20 and 30 days after challenge. This confirms the susceptibility of this species to the NDV, as demonstrated by Reis; Nóbrega (1956). This data demonstrates that white Pekin ducks are able to eliminatetheN DV from20 up to30daysafter infection, which is very important for the epidemiology of this disease.

Unfortunately, there is no information about the importanceof whitePekin ducksasN DV carrier, or as to the potential risk factor of thedissemination of the Newcastle disease by Pekin ducks to other foodproducing poultry, such asturkeys, broilers, breeders and layers, that may beraised closeto thePekin duck habitat. In contrast, the NDV was not isolated from groups of Pekin ducks that were vaccinated against the NDV. It suggests that vaccination can efficiently eradicate this virus in Pekin ducks and can be an importanttool for theepidemiological control of NDV dissemination to other poultry species. Further studies should be developed to establish the importance of whitePekin ducksas N DV carrier, disseminating the disease in the field.

\section{CONCLUSIONS}

1. WhitePekin ducks showed to beresistant to the development of clinical signsof ND when challenged with velogenic NDV.
2. It was demonstrated, in theepidemiology of the NDV, the relevance of white Pekin ducks that can eliminatethevirusfrom 20 to 30 days after challenge.

3. Vaccination againstND isimportant to prevent the elimination of the virus in the field.

REFERENCES

HIGGINs, D.A. Nine disease outbreaks associated with myxoviruses among ducks in Hong Kong. Tropical A nimal H ealth and Production , v.3, p.232-236, 1971.

Kaleta,E.;Beldauf, C. Newcastlediseaseinfreelivingand pet birds. In: Alexander, D. (Ed.). N ewcastle disease. Boston: Kluwer Academic, 1988. p.197-246.

Office International DesEpizootes. M anual for animal disease reporting to the OIE. Paris: World Organization for Animal Health, 1996.

Paulitlo, A.C. D oença de N ewcastle: estudo experimental da resposta imuneàs estirpes vacinais B1 eLaSota. 1980. 84p. Dissertação (Mestrado) - Instituto de Ciências Biomédicas, Universidade de São Paulo, São Paulo, 1980.

PAulillo, A.C. Estudo experimental da resposta imunitária às vacinas inativada (ol eosa) e viva (amostra LaSota) contraa doença de $\mathrm{N}$ ew castle. 1984. 129p. Tese (Doutorado) Instituto de Ciências Biomédicas, Universidade de São Paulo, São Paulo, 1984.

PAuliLlo, A.C. A valiação da resposta imune e da performance zootécnica de poedeiras vacinadas experimental mentecontra a doença de N ewcastle. 1989. 116p. Tese (Livre Docência) - FaculdadedeCiências A grárias eVeterinárias, Universidade Estadual Paulista, Jaboticabal, 1989.

Paulillo, A.C.; Pinto,A.;A rikı, J.; Berchieri Junior, A.Doença de N ewcastle. I. Estudo experimental da resposta imune às estirpes vacinais Bl e LaSota. Revista da FaculdadedeM edicina $V$ eterinária eZ ootecnia daU niversidade de São Paulo, v.19, n.1, p.9-43, 1982.

Paulillo, A.C.; M ostassier, H.J.;Richtzenhain, L.J.;N AKaghi, L.S.L.; Barbosa, J.C.; Cevintana, J.L.; Montassier, H.J.; Berchieri Junior, A.; ArIKI, J. Doença de N ewcastle. IV. Ensaio experimental dediferentes vias devacinação comaestirpelentogênicaLaSota em frangosdecorte. Ars V eterinaria, v.3, n.1, p.73-79, 1987. 
Paulitlo, A.C. Estudo zootécnico e imunológico de aves decortesubmetidas a diferentes programas devacinação contra a doença de Newcastle. In: REUNIÃO ANUAL DA SOCIEDADE BRASILEIRA DE ZOOTECNIA, 33., 1996, Fortaleza, CE. A nais. Fortaleza: 1996. p.388-390.

Reis, J.; Nóbrega, P. Tratado de doença das aves. 2.ed. São Paulo: Edições Melhoramentos, 1956. p.254.

Reed, J.L.; Muench, H.A. Simple method of estimating percent and points. A merican Journal of $\mathrm{H}$ ygiene, v.27, p.493-497, 1938.
U.S. Code Of Federal Regulations A nimal and animal products. Washington: Federal Register $\mathrm{N}$ ational Archives And Records Administration, 1993. $818 p$.

Received on 29/ 8/ 06 Accepted on 17/ 9/ 07 